\title{
EFFECTS OF THERMAL ENVIRONMENT AND SUPPLEMENTATION LEVELS ON THE PHYSIOLOGICAL PARAMETERS OF MOXOTÓ GOATS IN CONFINED AND SEMI-CONFINED RISING SYSTEMS
}

\section{DERMEVAL A. FURTADO ${ }^{1}$, CARLOS A. V. GOMES ${ }^{2}$, ARIOSVALDO N. MEDEIROS ${ }^{3}$, EDGARD C. PIMENTA FILHO ${ }^{3}$, VALDI L. JÚNIOR ${ }^{5}$}

\begin{abstract}
The objective of this work was to determine the effect of environmental variables and supplementation levels on physiological parameters of Moxotó goats in confined and semiconfined rising systems, in the Brazilian semi-arid region. The semi-confined individuals were kept on a grass based diet during the day and arrested in the end of the afternoon. The confined animals were kept in a management center, receiving two diets composed by forage cactus and maniçoba hay into two different levels ( 0.5 and $1.5 \%$ of the body weight). Inside the management center and in the external environment the environmental comfort parameters were set high during the afternoon period characterizing a situation of thermal discomfort for the animals. During the morning the semi-confined animals presented an average respiratory frequency $\left(69.5 \mathrm{mov} \mathrm{min}^{-1}\right)$ and rectal temperature $\left(39.5{ }^{\circ} \mathrm{C}\right)$ higher than the confined ones $\left(62.6 \mathrm{mov} \min ^{-1}\right.$ and $39.0{ }^{\circ} \mathrm{C}$, respectively). The confined and semi-confined animals were able to maintain their rectal temperature within normal limits, with increase in the cardiac beatings rate and respiratory frequency. The greater percentage of the used supplementations $(1.5 \%)$ seemed to increase rectal temperature in the two studied rising systems.
\end{abstract}

KEYWORDS: thermoregulation, environmental variables, native goat race, semi-arid.

\section{EFEITO DO AMBIENTE TÉRMICO E SUPLEMENTAÇÃO NAS VARIÁVEIS FISIOLÓGICAS DE CAPRINOS MOXOTÓ EM CONFINAMENTO E SEMICONFINAMENTO}

\begin{abstract}
RESUMO: Este trabalho teve os objetivos de determinar e de avaliar o efeito das variáveis ambientais e quantidade de suplementação, com concentrados, nas variáveis fisiológicas de caprinos Moxotó, confinados e semiconfinados, no semi-árido nordestino. Os animais semiconfinados foram mantidos em regime de pasto durante o dia e recolhidos ao final da tarde. Os animais confinados foram mantidos em um centro de manejo, recebendo duas dietas compostas por palma forrageira e feno de maniçoba, com duas quantidades de concentrados $(0,5$ e $1,5 \%$ do peso vivo). No interior do aprisco e no ambiente externo, os índices de conforto ambiental ficaram elevados no período da tarde, caracterizando situação de desconforto térmico para os animais. No período da manhã, os animais semiconfinados apresentaram freqüência respiratória média de 69,5 mov $\min ^{-1}$ e temperatura retal de $39,5{ }^{\circ} \mathrm{C}$, mais elevadas que os confinados $\left(62,6 \mathrm{mov}^{\mathrm{min}}{ }^{-1} \mathrm{e}\right.$ $39,0{ }^{\circ} \mathrm{C}$, respectivamente). Tanto os animais confinados como os semiconfinados conseguiram manter a temperatura retal dentro dos limites normais, havendo aumento nos batimentos cardíacos e na freqüência respiratória. Maior percentagem de suplementação $(1,5 \%)$ provocou aumento na temperatura retal, nos dois sistemas de criação.
\end{abstract}

PALAVRAS-CHAVE: termorregulação, variáveis ambientais, caprino nativo, semi-árido.

\footnotetext{
${ }^{1}$ Prof. Dr., Agriculture Engineering Department, UFCG, Campina Grande - PB, Brazil, dermeval@deag.ufcg.edu.br.

${ }^{2}$ Zootechnician, M.Sc. in Zootechnics, Areia - PB, Brazil.

${ }^{3}$ Professors at Zootechnics Department, CCA/UFPB, Areia - PB, Brazil.

${ }^{4}$ Master of the Course on Zootechnics Doctorship, CCA/UFPB, Areia - PB, Brazil.

Received by Editorial Board on September, 12, 2006
}

Approved by the Editorial Board on September, 22, 2008 


\section{INTRODUCTION}

The understanding of the behavioral standards and the physiological knowledge of the animals in a tropical environment are essential for the development of the management practice, in view of a better performance of the animals. The animal sensibility to stress and heat and their productive performance are affected in greater or lesser scope, depending on the intensity and time length of the stress (CEZÁRIO et al., 2005). The accurate identification of the factors that influence the animal productive life, such as the stress imposed by the seasonal flow of the environment allow adjustments in the management practices of the production systems, thus granting them the sustainability and economic viability (TURCO et al., 2004).

BAÊTA \& SOUZA (1997) and SILVA (2000) describe this thermic stress as all the combinations of the environmental conditions which cause the effective environment to be greater than the thermoneutral area of the animal. For TITO (1998), the thermic comfort area is the band of the environmental temperature band in which the homeothermic animal does not its regulator system, and of which the productive effectiveness is elevated. According to McDOWELL (1989), the two main forms of adequacy assessment of a certain race or animal to warm environments are the physiological adaptations mainly represented by the alterations of the thermic balance as well as the adaptability of a certain performance, which describe the modifications of such performance when the animal is submitted to high temperatures.

In accordance to SILVA (2000), the thermolisys mechanism considered to be the most effective for the ruminants bred in tropical areas is the evaporating one. Part of such a mechanism occurs by means of the airways tracts and partly by the skin way. Therefore, the occurrence of this thermic stress can be diagnosed by the increase of the rectal temperature, respiratory rate and sweat rate. Some mechanisms that combat the excessive temperature are the increase of the respiratory rate, food intake reduction, water intake increase and activity decrease at the warmest hours of the day. By measuring the rectal temperature and the respiratory rate of an animal it is possible to infer about its thermic comfort in a certain environment; based on these data, it is possible to search for options to minimize the stress (TEIXEIRA \& MODESTO, 2005).

For LUCCI (1977), the animal foods that have low portion of volume are to be the most recommended for the tropical conditions (in relation to a lower caloric increment). In conformity with HAFEZ (1973), the food composed exclusively of volume promoted higher body temperatures and higher respiratory rates in relation to the concentrates-rich foods

The eating habits and the goats capacity of selecting the ingested food, in comparison to the other ruminants, such as the sheep and cattle are to be taken into account in proposition of the food systems, either in pasture conditions, or feeding at trough, seen it influence both in the quality and quantity of the in-taken food (MORAND-FEHR, 1991 e SANTOS, 1994).

In situations in which the pastures and/or the voluminous are not enough to fulfill the nutritive demand of the animals, it is fundamental the supplementation with the concentrates of which enable the expression of the production potential, and whose answers depend essentially on the quality of the food offered and on the animal breeding.

The experience aimed the determination and the evaluation of the environmental variable effects and of the supplementation quantity with the concentrates within the physiological parameters of the confined and semi-confined Moxotó goats.

\section{MATERIAL AND METHODS}

The experience was conducted at the Experimental Station of São João do Cariri, a physical base which belongs to the Agrarian Sciences Center of UFPB, and that is located in the semi-arid zone of the State of Paraíba, Brazil. The experimental period occurred from September 2004 to January 2005, and 32 animals of Moxotó race were used, all of them were male and weaned vermifuged and with the average weight of $10 \mathrm{~kg}+3.5$. Two systems of production were used, in 
which the first one, the animals were kept in semi-confinement, and during the day they were kept in pasture in paddocks that consisted of native pasture, with the predominance of white forest plants (Caesalpinia bracteosa), Cocksfoot grass (Aristida setifolia), Mororó (Bauhinia cheilantha) and Malva (Malva moose). By late afternoon, at 17 hours, the animals were collected into the center management to stay in individual stalls on earth ground floor directed towards north-south, at the dimensions of $1.0 \mathrm{~m} \mathrm{x} 1.5 \mathrm{~m}$

In the second system, the animals were kept in total confinement in the management center, whose facilities were on earth ground directed towards north-south, at the height of $2.5 \mathrm{~m}$, and wooden cover of clay tile. In that place, the animals received the voluminous diet, the nearest to the one fed to the semi-confined animals. The diet was based on the consumption analyze by the fistule-esophaged animal and which were also kept in semi-confinement whereby in the pickets they were held with special bags for the collection of wastes and subsequent identification of the quantity and quality of the grazed material. Both the confined and the semi-confined animals received daily supplementation with two quantities of concentrate ( 0.5 and $1.5 \%$ of body weight $)$. In the case of the confined animals, the supplementation was held in stalls inside the facilities. For the semi-confined animals, the supplementation was carried out in stalls within the center of management, in the late afternoon.

The internal environmental variables were obtained at 9 and $15 \mathrm{pm}$, three days a week, being collected from the dry bulb temperature (Tbs), the wet bulb temperature (Tbu), the black globe temperature (TGN) and wind speed (Vv) throughout the experimental period. To obtain the wind speed in $\mathrm{m} \mathrm{s}^{-1}$, a digital anemometer was used, and for the Tbs and Tbu, it was used a psychrometer, with accuracy of $1.0^{\circ} \mathrm{C}$, range from -10 to $50^{\circ} \mathrm{C}$. The Tgn was obtained with a thermometer, at the scale of $1.0^{\circ} \mathrm{C}$, inserted into a darkened ball with black ink of high absorption.

From the figures obtained by means of the environmental variables, we determined, within and outside the storehouses, the relative air humidity $(\mathrm{RH})$ and the black globe temperature index and humidity (ITGU), thus obtained from the words quoted by BUFFINGTON et al. (1977):

where,

ITGU Tgn $=0.36+$ Td -330.08

Tgn - the black globe temperature, and

$\mathrm{Td}$ - temperature of the dew point, both expressed in $\mathrm{K}$.

The heat load of radiation (CTR) was calculated within and outside the facility, whose expression was quoted by ESMAY (1969):

where,

$$
\mathrm{CTR}=\sigma(\mathrm{TRM})^{4}
$$

CTR - load thermal radiation, $\mathrm{W} \mathrm{m}^{-2}$;

$\sigma$ - Stefan-Boltzman constant $\left(5.6710^{-8} \mathrm{~W} \mathrm{~m}^{-2} \mathrm{~K}^{-4}\right)$, and

TRM - average temperature radiant, $\mathrm{K}$.

TRM is a temperature considered uniformly black that eliminates the effect of reflection, with which the body (black globe) exchange as much energy as the amount of environmental consideration (BOND et al., 1954). The TRM was obtained by the equation (3):

where,

$$
\mathrm{TRM}=100\left[2.51 \mathrm{v}^{1 / 2}\left(\mathrm{~T}_{\mathrm{gn}}-\mathrm{T}_{\mathrm{a}}\right)+\left(\mathrm{T}_{\mathrm{gn}} / 100\right)^{4}\right]^{1 / 4}
$$

$\mathrm{v}$ - wind speed, $\mathrm{m} \mathrm{s}^{-1}$, and

$\mathrm{Ta}$ - environmental temperature, $\mathrm{K}$

The instruments to measure the weather were installed in the center of management to $1.0 \mathrm{~m}$ above the floor, at the enough height to ensure that animals do not damage the equipment. The 
external environmental variables were obtained in the Meteorological Station of Basin School in the Experimental Station of São João do Cariri - PB, with the exception of Tgn, which was obtained with a black globe thermometer, installed outside the meteorological station, at $1 \mathrm{~m}$ in height above the ground. The animals of both treatments were fed daily with concentrates, in accordance with the composition shown in Table 1.

TABLE 1. Ingredients and composition of the daily diet supplement for the animals.

\begin{tabular}{lcrrccccc}
\hline Ingredients & MS (kg) & PB (kg) & EM (Mcal) & FDN (\%) & FDA (\%) & EE (kg) & Ca (\%) & P (\%) \\
\hline Corn & 61.50 & 5.54 & 1.71 & 6.09 & 2.03 & 2.28 & 0.02 & 0.18 \\
Soy flour & 20.50 & 10.25 & 0.65 & 2.56 & 1.82 & 0.35 & 0.08 & 0.13 \\
Wheat flour & 15.00 & 2.40 & 0.34 & 6.29 & 1.68 & 0.62 & 0.02 & 0.21 \\
Calcary & 1.00 & 0.00 & 0.00 & 0.00 & 0.00 & 0.00 & 0.36 & 0.00 \\
Mineral Supplement & 2.00 & 0.00 & 0.00 & 0.00 & 0.00 & 0.00 & 0.60 & 0.15 \\
\hline Total & 100.00 & 18.19 & 2.70 & 14.94 & 5.53 & 3.25 & 1.08 & 0.67 \\
\hline
\end{tabular}

MS - dry material; PB - gross protein; EM - metabolizable energy; FDN - fiber in neutral detergent; FDA - fiber in acid detergent; $\mathrm{EE}$ - stratum ether; $\mathrm{Ca}$ - calcium; $\mathrm{P}$ - phosphorus.

For the collection of physiological parameters, the semi-confined animals were collected from the paddock for about 30 minutes before the measures, being at rest in the center of management in uncovered stalls for a later collection of the frequencies and respiratory rates and rectal temperature in two readings a day ( 9 to 15 hours), three times a week, on the same day to collect environmental data. In the case of the confined animals the physiological data collection occurred inside the facility.

The respiratory rate (FR) was obtained by the auscultation with the help of a flexible stethoscope on the first rib of the right chest, and by counting the number of movements for 20 seconds, whose value obtained was multiplied by 3 , the heart movements were determined by

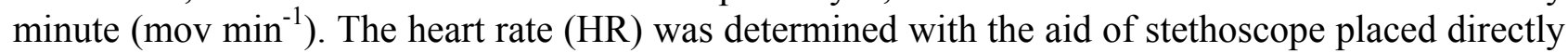
on the left chest, that counted the number of beats for 20 seconds, whose value was obtained by the multiplication by 3 , and the heart beats were determined per minute (beats $\min ^{-1}$ ). To obtain the rectal temperature (RT), it was introduced a veterinary clinical thermometer, $5 \mathrm{~cm}$ into the rectum of the animal, which stayed for a period of 2 minutes and the result of the measurement was expressed in degrees centigrade.

The experimental design was completely randomized (DIC), under the subplots, with four treatments and eight repetitions, taking as the main plot and subplot supplementation levels of the hour. The environmental variables were subjected to statistical program SAEG (SAEG, 1997), with analysis of variance for hours and levels of supplementation, compared with the averages for Tukey test, a $5 \%$ probability, using the equation (4):

$$
\mathrm{Yijk}=\mu+\mathrm{Si}+1_{\mathrm{a}(\mathrm{ik})}+\mathrm{Hj}+\mathrm{SH}_{\mathrm{ij}}+1_{\mathrm{b}(\mathrm{ijk})}
$$

where,

Yijk - variable analyzed;

$\mu$ - overall average;

$\mathrm{Si}$ - effect of supplementation;

$1_{\mathrm{a}(\mathrm{ik})}$ - error of the main portion;

$\mathrm{Hj}$ - end of the hour;

$\mathrm{SH}_{\mathrm{i} j}$ - interaction supplementation and time, and

$l_{b(i j k)}$ - experimental error.

\section{RESULTS AND DISCUSSION}

The average values of the meteorological variables of the internal environment, wherein the animals were confined, and the external environment, wherein the animals were semi-confined, ie, 
air temperature (TA), wind speed, (Vv), the relative humidity air (RH), black globe temperature (NGT), index of black globe temperature and humidity (ITGU) and thermal load of radiation (CTR) assessed during the trial period, are found in Table 2 . There were significant differences $(\mathrm{P}<0.05)$ between the internal and external TA. Mean internal TA, both in the morning $\left(29.2^{\circ} \mathrm{C}\right)$ and in the afternoon $\left(33.5{ }^{\circ} \mathrm{C}\right)$ were higher than the averages for the external TA $\left(26.4\right.$ and $31.9{ }^{\circ} \mathrm{C}$, for the periods in the morning and afternoon, respectively).

The internal TA was higher because of thermometers that measured the TA are in an external weather and TA under internal within the facilities, indirectly influenced by solar radiation, but also the heat released by the animals. The TA in the afternoon, both internal and external, was higher than those in the morning, as it was naturally expected. In the morning, the TA internal and external was found inside the zone of comfort for goats, which, according to SILVA (2000), should be between 20 and $30{ }^{\circ} \mathrm{C}$. Different situation occurred in the afternoon, to values exceeding the upper limit of critical temperature for this species. TA higher than this study were found by OLIVEIRA et al. (2005), which received TA environment in the sun of $35.0^{\circ} \mathrm{C}$, at the shadow of $30.3{ }^{\circ} \mathrm{C}$, FEITOSA et al. (2005) cited a TA shaded environment of $33.8^{\circ} \mathrm{C}$.

TABLE 2. The average values of the environmental internal and external variables, air temperature, wind speed, humidity, temperature of world trading, index of black globe temperature and humidity and heat load of radiation.

\begin{tabular}{lrrrr}
\hline & \multicolumn{2}{c}{9 hours } & \multicolumn{2}{c}{15 hours } \\
\cline { 2 - 5 } & Confined & Semi-confined & Confined & Semi-confined \\
\hline Air temperature $\left({ }^{\circ} \mathrm{C}\right)$ & $29.2 \mathrm{c}$ & $26.4 \mathrm{~d}$ & $33.5 \mathrm{a}$ & $31.9 \mathrm{~b}$ \\
Wind speed $\left(\mathrm{m} \mathrm{s}^{-1}\right)$ & $2.7 \mathrm{ab}$ & $4.3 \mathrm{a}$ & $2.9 \mathrm{ab}$ & $3.8 \mathrm{a}$ \\
Relative humidity $(\%)$ & $56.0 \mathrm{a}$ & $52.5 \mathrm{a}$ & $33.4 \mathrm{~b}$ & $30.3 \mathrm{~b}$ \\
The black globe temperature $\left({ }^{\circ} \mathrm{C}\right)$ & $26.9 \mathrm{c}$ & $41.8 \mathrm{a}$ & $31.5 \mathrm{~b}$ & $44.3 \mathrm{a}$ \\
Index temp, the black globe humidity & $79.3 \mathrm{~d}$ & $89.5 \mathrm{~b}$ & $85.9 \mathrm{c}$ & $94.5 \mathrm{a}$ \\
Heat load of radiation $\left(\mathrm{W} \mathrm{m}^{-2}\right)$ & $540.2 \mathrm{c}$ & $981.5 \mathrm{a}$ & $632.7 \mathrm{~b}$ & $1,008.2 \mathrm{a}$ \\
\hline
\end{tabular}

The averages that followed the same line in the letter do not differ at $5 \%$ of probability, by Tukey test.

In both periods, the $\mathrm{Vv}$ did not differ $(\mathrm{P}>0.05)$ from the internal and external environments. $\mathrm{Vv}$ reached in the morning, in both environments, the average speeds of $2.7 \mathrm{~m} \mathrm{~s}^{-1}$ and $4.3 \mathrm{~m} \mathrm{~s}^{-1}$, respectively. In the afternoon, those averages were $2.9 \mathrm{~m} \mathrm{~s}^{-1}$ and $3.8 \mathrm{~m} \mathrm{~s}^{-1}$, respectively. According to McDOWELL (1989), winds with speeds of 1.3 to $1.9 \mathrm{~m} \mathrm{~s}^{-1}$ are ideal for the creation of domestic animals, causing concerns when it reaches $8.0 \mathrm{~m} \mathrm{~s}^{-1}$. Increased ventilation is important in the process of thermoregulation, by influencing the elimination of sweat from the body surface, ie, the greater ventilation the greater dissipation of the body heat.

There were no differences $(\mathrm{P}>0.05)$ in $\mathrm{RH}$, comparing the environments (semi-confined and confined ones), both in the morning and in the afternoon, whose highest environmental variable was found in the morning, by decreasing in the period of the afternoon in both environments, which is associated with higher natural incidence of heat during that period.

For BAÊTA \& SOUZA (1997), the acceptable values of RH are between 50 and $80 \%$, while for NÄÄS (1989), the ideal is more limited, with average humidity of $75 \%$. Building on these values, it was observed that in the morning, the animals were exposed to conditions within that range. The period of the afternoon was characterized by a situation of thermal discomfort. The results found in this study were lower than those found by CEZAR et al. (2004) and similar to those reported by Oliveira et al. (2005). According to Ferreira (2005), very low relative humidity can promote the dissipation of heat through the evaporative process, but it also may cause heat stress through the dryness of mucous membranes and respiratory tract, in addition to promoting an increase in solid particles in suspension.

The external environment had Tgn higher $(\mathrm{P}<0.05)$ than the internal environment in both periods. Results similar to this work for the internal environment, were found by SOUZA et al. 
(2005) and CEZAR et al. (2004) that worked with goats in the semi-arid region of Paraiba, and which received daily average of 28.57 and $31.1^{\circ} \mathrm{C}$, respectively.

With respect to ITGU, we observed a significant difference $(\mathrm{P}<0.05)$ between the external and internal environment, both in the morning and in the afternoon, and the external environment in ITGU was found to be higher than the internal environment. According to the citation of various authors (SANTOS et al., 2005; SILVA et al., 2006a and SILVA et al., 2006b), to work with goats in the semi-arid Northeast, ITGU values of over 78 were considered and outside the zone of comfort for goats, although it does not have a definitive classification yet, particularly with native animals of the region.

There were differences $(\mathrm{P}<0.05)$ during the periods of morning and afternoon for the values of CTR, in internal and external environments, which were found to be higher in the external environment at 981.5 and $1008.2 \mathrm{~W} \mathrm{~m}^{-2}$, for periods of morning and afternoon respectively, with no difference between them. OLIVEIRA et al. (2005) considered that CTR up to $520 \mathrm{~W} \mathrm{~m}^{-2}$ features an uncomfortable situation for heat sheep in semi-arid northeast. MORAES et al. (2004), by analyzing the effect of season on the characteristics of thermoregulation goats in the semiarid region, noted that both the dry season, as the rainy season, the values of CTR were higher than those considered suitable for goats.

The averages of physiological variables respiratory rate (RR), heart rate (HR) and rectal temperature (RT), depending on the time of observation and levels of supplementation in the diet, are described in Table 3. For FR, no difference was observed $(\mathrm{P}>0.05)$ between the levels of supplementation of the diet in the morning, between confined and semi-confined animals.

TABLE 3. The averages of physiological parameters respiratory rate (FR), heart rate (FC) and rectal temperature (TR).

\begin{tabular}{|c|c|c|c|c|}
\hline \multirow{2}{*}{$\begin{array}{c}\text { Levels of } \\
\text { Supplementation }(\%)\end{array}$} & \multicolumn{2}{|c|}{ Morning - 9 am } & \multicolumn{2}{|c|}{ Afternooon - 15 pm } \\
\hline & Confined & Semi-confined & Confined & Semi-confined \\
\hline & \multicolumn{4}{|c|}{ Respiratory rate $\left(\mathrm{mov} \mathrm{min}^{-1}\right)$} \\
\hline 0.5 & $42.2 \mathrm{bB}$ & $72.3 \mathrm{aA}$ & $67.9 \mathrm{bA}$ & $78.3 \mathrm{aA}$ \\
\hline 1.5 & $63.1 \mathrm{bB}$ & $65.8 \mathrm{aA}$ & $77.1 \mathrm{aA}$ & $65.7 \mathrm{aA}$ \\
\hline \multicolumn{5}{|c|}{ Heart rate (beats $\min ^{-1}$ ) } \\
\hline 0.5 & $113.5 \mathrm{aA}$ & $106.6 \mathrm{aA}$ & $112.0 \mathrm{aA}$ & $102.6 \mathrm{aA}$ \\
\hline 1.5 & $112.8 \mathrm{aA}$ & $104.4 \mathrm{aA}$ & $119.8 \mathrm{aA}$ & $101.3 \mathrm{aA}$ \\
\hline \multicolumn{5}{|c|}{ Rectal temperature $\left({ }^{\circ} \mathrm{C}\right)$} \\
\hline 0.5 & $38.9 \mathrm{bC}$ & $39.5 \mathrm{aB}$ & $39.7 \mathrm{aA}$ & $39.9 \mathrm{aA}$ \\
\hline 1.5 & $39.1 \mathrm{aC}$ & $39.4 \mathrm{aB}$ & $39.6 \mathrm{bA}$ & $40.0 \mathrm{aA}$ \\
\hline
\end{tabular}

The average followed by same letter, uppercase and lowercase letters column on the line, do not differ at $5 \%$ of probability, by Tukey test.

There were no differences between groups and periods with regard to the FR, except for animals confined in the morning, which showed lower values for the measure. This behavior can be assigned to the management associate at room temperature, in which the animals of this group were kept quieter than the others. In the afternoon, the animals were confined to concentrate on the order of $1.5 \%$ of body weight that had higher frequency $(\mathrm{P}<0.05)$ than those who were concentrated at the base of $0.5 \%$ of body weight. This result conflicts with that one provided by HAFEZ (1973), which states that diet with a lower proportion of forage results in lower respiratory rate.

It was estimated that the FR of the animals was increased, as a way of dissipating heat to maintain homeothermic. According REECE (1996), the RF and goats is 12 to $25 \mathrm{mov} \mathrm{min}^{-1}$. The results of this study differed from those found by NEIVA et al. (2004) who, working with sheep kept in the sun, found higher values, regardless the content of feed concentrate in the diet. Moreover, similar to those values reported by NUNES et al. (2003) it was found values of RF at 
$79 \mathrm{mov} \mathrm{min}^{-1}$ in the afternoon, and lower than those found by SANTOS et al. (2004) who, working with goats on pasture, found mov FR of $91.6 \mathrm{~min}^{-1}$.

SILANIKOVE (2000) suggested a classification for the condition of heat stress on animals through the respiratory rate, in which the animals showed the rate between 40 and $60 \mathrm{mov} \mathrm{min}^{-1}$ and were classified with low stress, from 60 to $80 \mathrm{mov} \mathrm{min}^{-1}$ average of stress, from 80 to $120 \mathrm{mov} \mathrm{min}^{-1}$ high, and over $120 \mathrm{mov} \mathrm{min}^{-1}$ severe stress. Based on these figures, it appears that the condition of animals is subject to medium stress. The animals use to increase the dissipation of heat through the skin and the respiratory route as a mechanism for compensation against a rise in body temperature (MaCMANAUS, 1995).

There was no significant difference in the HR $(\mathrm{P}>0.05)$ measured in animals subjected to different levels of supplementation, nor between the periods. According to KELLY (1976) and MERK MANUAL OF VETERINARY (2008), the CR standard for goats varies between 70 and 90 beats $\mathrm{min}^{-1}$, and the results found in this work above that threshold, indicated an increase in HR in response to changes in environmental variables. When the animal is exposed to high temperatures, the physiological mechanisms of thermoregulation are activated. All the factors are added to the animal's genetic ability to respond to a specific stressful situation, which takes the animal to normal status (CUNNINGHAM, 2004). The results found in this work are above those described by AZEVEDO (1982), who observed values of HR of 84.2 beats $\mathrm{min}^{-1}$ for goats in the semi-intensive, and by SILVEIRA (1999), noted that an average of $84.8 \mathrm{~min} \mathrm{bat}^{-1}$ in goats in the semi-arid region of Paraiba.

Only the animals were confined under the influence of supplementation on measures of TR, both in the morning and in the afternoon, but in reverse. In the afternoon, the highest level of supplementation was associated with lower temperature, which is in agreement with the statement HAFEZ (1973). However, in the morning, the opposite occurred, which could show interactive effect with the environmental temperature, ie, temperatures in the area of comfort, that more concentrated level of supplementation would increase caloric larger, while in higher temperatures, the demand for energy to keep homeothermic promotes higher use of the concentrate, causing it to a bulky portion of greater responsibility for the caloric increase. Differences in environmental variables, under which the two groups were subjected, in addition to the aspects of management and behavior, can explain the fact that the level of supplementation had no effect on TR animals in semi-confinement.

Semi-confined animals in the morning showed greater TR because of the higher values of TA, ITGU CTR and the external environment. In the afternoon, no significant effect was observed in TR between the systems, probably by the influence of environmental variables, which were above the zone of thermal comfort. CEZAR (2004), working in semi-arid area, at environmental terms with ITGU of 82.4, found similar results for this work, whose TR was at 39.5 and $40{ }^{\circ} \mathrm{C}$ in the morning and afternoon respectively. It was observed that the TR in the afternoon was higher than in the morning for both confinement systems, and in that period, the TA was higher. Even under high environmental status, the confined animal and semi-TR remained confined within the normal range, which according to REECE (1996) should be between 38.5 and $39.7^{\circ} \mathrm{C}$. The results found in this study are similar to those found by SANTOS et al. (2005), who observed that the Moxoto goats had TR at $39.2{ }^{\circ} \mathrm{C}$ in the morning, in a state of comfort, and afternoon $\mathrm{TR}$ at $40.16{ }^{\circ} \mathrm{C}$ in a situation of heat stress.

\section{CONCLUSIONS}

The semi-confined animals had respiratory rate and rectal temperature higher than the confined animals, but the Moxotó goats managed to maintain rectal temperature in the normal range, with an increase o the respiratory rate as a mechanism of heat dissipation.

The supplementation level led to distinctive responses to what concerns to rectal temperatures, only for confined animals and in a reversed form in conformity to the period take, 
which requires the need of deeper studies that search for the trend confirmation and better understanding of the physiological processes

\section{ACKNOWLEDGEMNTS} research.

To the Scientific and Technological Council - CNPq, for the sponsorship of the present

\section{REFERENCES}

AZEVEDO, S.A. Estudos da freqüência cardíaca e da temperatura corporal de cabras (Capra hircus, L.) da raça Moxotó e suas modificações influenciadas pela gestação e lactação. 1982. $52 \mathrm{f}$. Dissertação (Mestrado em Zootecnia) - Universidade Federal Rural de Pernambuco, Recife,1982.

BAÊTA, F.C.; SOUZA. C.F. Ambiência em edificações rurais: conforto animal. Viçosa: UFV, 1997. $246 \mathrm{p}$.

BOND, T.E.; KELLY, C.F.; ITTER, N.R. Radiation studies of painted shade materials. Transaction of the ASAE, St. Joseph, Michigan, v.35, n.6, p.389-92, 1954.

BUFFINGTON, C.S.; COLLAZO-AROCHO, A.; CANTON, G.H.; PITT, D. Black globe humidity comfort index for dairy cows. St. Joseph: ASAE, 1977. 19 p.

CEZAR, M.F.; SOUZA, B.B.; SOUZA, W.H. Avaliação de parâmetros físiológicos de ovinos Dopper, Santa Inês e seus mestiços perante condições climáticas do trópico semi-árido nordestino. Ciência e Agrotecnologia, Lavras, v.28, n.3, p.641-20, 2004.

CEZÁRIO, A.S.; OLIVEIRA, A.B.; ALMEIDA, V.S. Influência das variáveis ambientais e alimentação na temperatura retal e freqüência respiratória em cabras confinadas. In: REUNIÃO ANUAL DA SOCIEDADE BRASILEIRA DE ZOOTECNIA, 42., 2005, Goiânia. Anais... Goiânia: Sociedade Brasileira de Zootecnia, 2005. 1 CD-ROM.

CUNNINGHAM, J.G. Tratado de fisiologia veterinária. 3.ed. São Paulo: Koogan, 2004. 528 p. ESMAY, M.L. Principles of animal environment. $2^{\text {nd }}$ ed. Westport: ABI Publishing, 1969. 325 p.

FEITOSA, A.S.; SANTOS, C.C.; ALMEIDA, V.S. Avaliação da adaptabilidade de cabras às condições climáticas do sudoeste da Bahia. In: REUNIÃO ANUAL DA SOCIEDADE BRASILEIRA DE ZOOTECNIA, 42., 2005, Goiânia. Anais... Goiânia: Sociedade Brasileira de Zootecnia, 2005. 1 CD-ROM.

FERREIRA, R.A. Maior produção com melhor ambiente para aves, suínos e bovinos. Viçosa: Aprenda Fácil, 2005. 371 p.

HAFEZ, E.S.E. Adaptación de los animales domésticos. Barcelona: Labor, 1973. 563 p.

LUCCI, C.S. Clima e aclimatação de bovinos e leite no Brasil Central. Zootecnia, Nova Odessa, v.15, n.3 p.157-69, 1977.

KELLY, W.R. Diagnóstico clínico veterinário. 2.ed. México: Continental, 1976. 444 p.

MaCMANAUS, C. Comparação das raças Santa Inês e Bergamácia no Distrito Federal: características de adaptação em animais adultos. In: REUNIÃO ANUAL DA SOCIEDADE BRASILEIRA DE ZOOTECNIA, 32., 1995, Brasília. Anais... Brasília: Sociedade Brasileira de Zootecnia, 1995. p.136-7.

MANUAL MERCK DE VETERINÁRIA. 9.ed. São Paulo: Roca, 2008. 2.336 p.

McDOWELL, R.E. Bases biológicas de la producción animal en zonas tropicales. São Paulo: Ícone, 1989. $183 \mathrm{p}$. 
MORAES, D.A.E.F.; BENTO, C.A.P.; SOUZA JÚNIOR, S.C.; VASCONCELOS, A.M.; SOUZA, W.G. Efeito da época do ano sobre características termorreguladoras de caprinos, ovinos e bovinos na região semi-árida. In: CONGRESSO NORDESTINO DE PRODUÇÃO ANIMAL, 3., 2004, Campina Grande. Anais ... João Pessoa: SNPA/UFPB, 2004. 1 CD-ROM.

MORAND-FEHR, P. Feeding behaviour of goats at the trough. In: MORAND-FEHR, P. (Ed.) Goat nutrition. Wageningen: Pudoc, 1991. p.3-12.

NÄÄS, I.A. Princípios de conforto térmico na produção animal. São Paulo: Editora Ícone, 1989. $183 \mathrm{p}$.

NEIVA, J.N.M.; TEIXEIRA, M.; TURCO, S.H.N. Efeito do estresse climático sobre os parâmetros produtivos e fisiológicos de ovinos Santa Inês mantidos em confinamento na região litorânea do Nordeste do Brasil. Revista Brasileira de Zootecnia, Viçosa, v.33, n.3, p.668-78, 2004.

NUNES, A.S.; BARBOSA, O.R.; DAMASCENO, J.C. Respostas fisiológicas de cabras leiteiras submetidas ao regime de suplementação com concentrado em dois sistemas de produção. Acta Scientiarum, Maringá, v.25, n.1, p.157-63, 2003.

OLIVEIRA, F.M.M.; DANTAS, R.T.; FURTADO, D.A.; NASCIMENTO, J.W.B.; MEDEIROS A.N. Parâmetros de conforto térmico e fisiológicos de ovinos Santa Inês, sob diferentes sistemas de acondicionamento. Revista Brasileira de Engenharia Agrícola e Ambiental, Campina Grande, v.9, n.4, p.631-5, 2005.

REECE, W. O. Fisiologia de animais domésticos. São Paulo: Roca, 1996. p.137 e 254.

SAEG - SISTEMA DE ANÁLISE ESTATÍSTICA E GENÉTICA. Versão 7.1. Viçosa: UFV, 1997. 1 CD-ROM.

SANTOS, C.C.; BONOMO, P.; CEZÁRIO, A.S. Respostas fisiológicas de cabras Saanen, expostas ao sol e à sombra em ambiente tropical. In: REUNIÃO ANUAL DA SOCIEDADE BRASILEIRA DE ZOOTECNIA, 41., 2004, Campo Grande. Anais... Campo Grande: Sociedade Brasileira de Zootecnia, 2004. 1 CD-ROM.

SANTOS, F.C.B.; SOUSA, B.B.; ALFARO, C.E.P.; CÉSAR, M.F.; PIMENTA FILHO, E.C.; ACOSTA, A.A.A.; SANTOS, J.R.S. Adaptabilidade de caprinos exóticos e naturalizados ao clima semi-árido do Nordeste brasileiro. Ciência e Agrotecnologia, Lavras, v.29, n.1, p.142-9, 2005.

SANTOS, L.E. Hábitos e manejo alimentar de caprinos. In: ENCONTRO NACIONAL PARA O DESENVOLVIMENTO DA ESPÉCIE CAPRINA, 3., 1994, Jaboticabal. Anais... Jaboticabal: UNESP, 1994. p.1-27.

SILANIKOVE, N. Effects of heat stress on the welfare of extensively managed do mastic ruminants. Livestock Production Science, Amsterdan, v.67, n.1, p.1-18, 2000.

SILVA, E.M.N.; SOUZA, B.B.; SILVA, G.A.; CEZAR, M.F.; SOUZA, W.H.; BENICIO, T.M.A.; FREITAS, M.M.S. Avaliação da adaptabilidade de caprinos exóticos e nativos no semi-árido paraibano. Ciência e Agrotecnologia, Lavras, v.30, n.3, p.516-21, $2006 \mathrm{~b}$.

SILVA, G.A.; SOUZA, B.B.; ALFARO, C.E.P.; SILVA, E.M.N.; AZEVEDO, S.A.; AZEVEDO NETO, J.; SILVA, R.M.N. Efeito da época do ano e período do dia sobre os parâmetros físiológicos de reprodutores caprinos no semi-árido paraibano. Revista Brasileira de Engenharia Agrícola e Ambiental, Campina Grande, v.10, n.4, p.903-9, 2006a.

SILVA, R.G. Introdução à bioclimatologia animal. São Paulo: Nobel, 2000. 286 p.

SILVEIRA, J.O. de A. Respostas adaptativas de caprinos das raças Bôer e Anglo-Nubiano às condições do semi-árido brasileiro. 1999. Dissertação (Mestrado em Zootecnia) - Universidade Federal da Paraíba, João Pessoa, 1999. 
SOUZA, E.D.; SOUZA, B.B.; SOUZA, W.H. Determinação dos parâmetros físiológicos e gradiente térmico de diferentes grupos genéticos de caprinos no semi-árido. Ciência e Agrotecnologia, Lavras, v.29, n.1, p.177-84, 2005.

TEIXEIRA, M.C.; MODESTO, E.C. Parâmetros fisiológicos de novilhas mantidas em sistema de pastejo irrigado no semi-árido nordestino. In: REUNIÃO ANUAL DA SOCIEDADE

BRASILEIRA DE ZOOTECNIA, 42., 2005, Goiânia. Anais... Goiânia: Sociedade Brasileira de Zootecnia, 2005. 1 CD-ROM.

TITO, E.A.L. Clima: influência na produção de leite. In: SILVA, I.J.O. SIMPÓSIO BRASILEIRO DE AMBIÊNCIA NA PRODUÇÃO DE LEITE, 1., 1998, Piracicaba. Anais... Piracicaba, 1998. p.10-23.

TURCO, S.H.N.; ARAÚJO, G.G.L.; BADE, P.L. Respostas fisiológicas de caprinos e ovinos em confinamento a céu aberto, nas condições climáticas do semi-árido nordestino. In: REUNIÃO ANUAL DA SOCIEDADE BRASILEIRA DE ZOOTECNIA, 41., 2004, Campo Grande. Anais... Campo Grande: Sociedade Brasileira de Zootecnia, 2004. 1 CD-ROM. 